\title{
Analysis of sediment samples for some trace and major metals from Okaba coal mine in Kogi State, Nigeria by energy-dispersive x-ray fluorescence spectrometry: Effect of seasonal variations on the concentrations of these metals
}

\author{
E. O. OKORIE ${ }^{1^{*}}$ and J. N. EGILA ${ }^{2}$ \\ ${ }^{I}$ Department of Science Laboratory Technology, Federal Polytechnic Idah, \\ P.M.B. 1037 Idah, Kogi Sate, Nigeria. \\ ${ }^{2}$ Department of Chemistry, Faculty of Natural Sciences, University of Jos, \\ P.M.B 2084 Jos, Plateau State, Nigeria. \\ "Corresponding author, E-mail: e.okorieslt@yahoo.com; Tel: +234-8-059430990
}

\begin{abstract}
Coal sediment samples from Okaba coal mine in Kogi State, Nigeria, were subjected to analysis for some metallic and non-metallic compositions. Of 35 elements determined by energy-dispersive X-ray fluorescence spectrometry, a number of anomalously high levels were recorded. Elements determined are Al, $\mathrm{Si}, \mathrm{P}, \mathrm{S}, \mathrm{K}, \mathrm{Ca}, \mathrm{Ti}, \mathrm{Cr}, \mathrm{Mn}, \mathrm{V}, \mathrm{Fe}, \mathrm{Ni}, \mathrm{Cu}, \mathrm{Zn}, \mathrm{Rb}, \mathrm{Zr}, \mathrm{Ru}, \mathrm{Ba}, \mathrm{Sr}, \mathrm{Y}, \mathrm{Se}, \mathrm{Os}, \mathrm{Bi}, \mathrm{Sb}, \mathrm{Pb}, \mathrm{Mg}, \mathrm{Na}, \mathrm{Se}, \mathrm{Br}, \mathrm{As}, \mathrm{Cl}$, $\mathrm{Au}, \mathrm{Nb}, \mathrm{Hg}$ and $\mathrm{W}$. Most of the known or potential metal contaminants are included in this list. The extent of contamination of sediments by metals analysed is greatest for $\mathrm{Fe}$ and then in decreasing order $\mathrm{Al}, \mathrm{K}, \mathrm{Ti}, \mathrm{Ru}, \mathrm{Zr}$, $\mathrm{Sb}, \mathrm{Pb}, \mathrm{Ba}, \mathrm{Cu}, \mathrm{V}, \mathrm{Mn}, \mathrm{Sr}, \mathrm{Cr}, \mathrm{Y}, \mathrm{Bi}, \mathrm{Rb}, \mathrm{As}, \mathrm{Au}, \mathrm{Sc}$ and $\mathrm{Os}$. Results are presented. It was observed from seasonal variations that flooding and leaching contributed to the increase in the concentrations of the metals studied at the downstream. Metals such as $\mathrm{Mg}, \mathrm{Na}, \mathrm{Se}, \mathrm{Os}, \mathrm{Bi}, \mathrm{Nb}, \mathrm{Hg}$ and $\mathrm{W}$ were not detected at all levels. Thus the coal mine contributed greatly to these concentrations in all the sediment samples. Seasonal variations play an important role in the concentrations of the metals studied. This was evident at the downstream part of the sediment samples were elevated concentrations were observed.
\end{abstract}

(C) 2014 International Formulae Group. All rights reserved.

Keywords: coal, trace metals, ED-XRF, sediments, seasonal variation.

\section{INTRODUCTION}

Coal is a fossil fuel extracted from the ground by minning. Coal is formed from plant remains that have been compacted, hardened, chemically altered and metamorphosed by heat and pressure over geologic time. Successive generations of plant growth and death formed deep deposits of unoxidized organic matter that were subsequently covered by sediments and compacted into carboniferous deposits such as peat or bituminous or anthracite coal.

Previous research on heavy metal presence in sediments and bioremediation has been carried out. Results of such study indicated that lagoon sediments at a coal mine site harbor $\mathrm{Se}^{6+}$ - and $\mathrm{Se}^{4+}$ - reducing bacteria and may be important sinks for soluble $\mathrm{Se}$ (Tariq et al., 2007). Other works by previous authors have shown the presence of heavy 
metals in coal sediments (FranciskovicBilinski, 2008; Hamilton-Taylor et al., 1988). The disruption of strata below ground by minning causes heavy metals to be oxidized and mobilized into water within or near the coal strata since multiple strata are impacted by the immediate act of minning or through tension-generated slumps or earth faulting in the aftermath, this contaminated soil and water, now unconfined, can seep into quality water veins and aquifers. The result is town irrigation and horticultural water supplies that are contaminated with heavy metals and other non-beneficial organic components from the coal strata. For example, concentrations of arsenic are of particular concern and there well-documented cases of poisoning of ground water by arsenic near coal-minning sites. It is also worthy to note that works that investigated coal sediment with the aim of determining the nature of the anthropogenic record has been recorded (Joy and Andrew, 1996). Previous authors have also recorded the sulphur and metallic contents of coal sediments (Zhang et al., 2008; Biswas et al., 2008; Widod et al., 2010; Triese et al., 1998; Alka and Tripathi, 2007; Adaikpoh et al., 2005). The source of enrichment in these sediments likely is related to human activity and coal minning. Elevated amounts of ferric iron precipitate in streams affected by coal minning have been reported (Porter et al., 1995) and arsenic released to the environment is quickly adsorbed onto the precipitates (Cullen and Reimer, 1989).

\section{Aim of study}

This research is intended to determine the bio-toxic levels of some metals and nonmetals in coal sediments that are capable of being absorbed by plants and farming animals in toxic levels, and thereby enter the food chain. Thus the analyses will be conducted to:

1. Determine the levels of contaminants available for movement in the environment;

2. Determine whether the contaminants found in the sediments were consistent and at levels that could yield the in-situ concentrations observed in receiving waters, and;

3. Evaluate whether the contaminant levels in one type of sediment were significantly lower than the other type, for assessment of alternative recommendations available to minimize environmental impacts.

Many of these elements have been implicated in causing cancers, cardiovascular, gastrointestinal and respiratory diseases. Certain heavy metals have been shown to impair immunity, cause both hepatic and renal disorders, be neurotoxic, especially to children, and are implicated in numerous other neurological and neuro behavioural problems, diabetes, bone disorders, blood disorders and general oxidative damage.

\section{MATERIALS AND METHODS}

\section{Historical background}

The Okaba coal mine is located in Ankpa Local Government Area of Kogi State in central region of Nigeria (Figures 1 and 2). The host community to the coal mine is Odagbo with a population of about two thousand inhabitants, and is situated on top of a hilly terrain underneath, the mineral deposit of coal. The drainage basin of Odagbo is primarily rural and crude with no industrial development. Among the companies operating in Odagbo are:

1.The Nigerian Coal Corporation which has been operating since 1967 until 2001 when it suspended minni9ng activities.

2. Nordic Nigeria limited which started minning operations in 1998 and has been engaged in active minning since then.

On a visit to the area on a sunny day, one will immediately perceive an obnoxious air with a choking pungent smell the whole community has been living with this air since 1967. The Odagbo mine site was started as a result of the Nigerian civil war in 1967-1970. The predominant coal minning area of Enugu (then Eastern Nigeria) was under the control of the breakaway republic of Biafra. This represented about ninety percent of the coal produced during the period in question. 
The minning companies drains untreated mine wastes into the nearby stream (Achokpa stream) which is the only source of drinking water to the host community and villages around the mine area. Surprisingly, however, villages living downstream have been living with this source of water for the past thirty seven years. The Achokpa stream is a spring-like valley stream emanating from the mountainous depressions of the area. The upstream point of collection from the source is about $1 \mathrm{Km}$. Seldom, the water has colour plausibly suggesting the influence of the underlying minerals along the valley basin as the water traverses its course. The water has a repulsive odour, and this could be ascribed to eutrophication and decomposition of organic matter in the water body (trees grow along the valley whose leaves are shed onto the stream). Furthermore, the inhabitants of Odagbo are peasant farmers, and their farms are mostly located in the plains of the depressions encompassing the valley. Therefore, during run-off minerals are further eroded onto the valleys stream thereby enriching its mineral concentration, and enhancing eutrophication.

The Omaji Oda stream is a highly polluted small valley stream located adjercent to the minning sites. Its flow heavily depends on rainfall and mine drainage from mine sites. It is coloured and the valley terrain is rocky. However, plants don't grow along the water course suggesting plausibly heavy pollution that is inimical to plant growth and moreover rocky terrain. This Omaji Oda stream is channeled to the downstream Achokpa as a tributary. A vast majority of land covering about six square kilometers have been rendered unfit for agricultural purposes due to overburden from minning excavations. Some used mine sites have remained unreclaimed after operations thereby destroying a vast land. The site is about four hundred meters from Odagbo and seven hundred meters from another host community, Udaba.

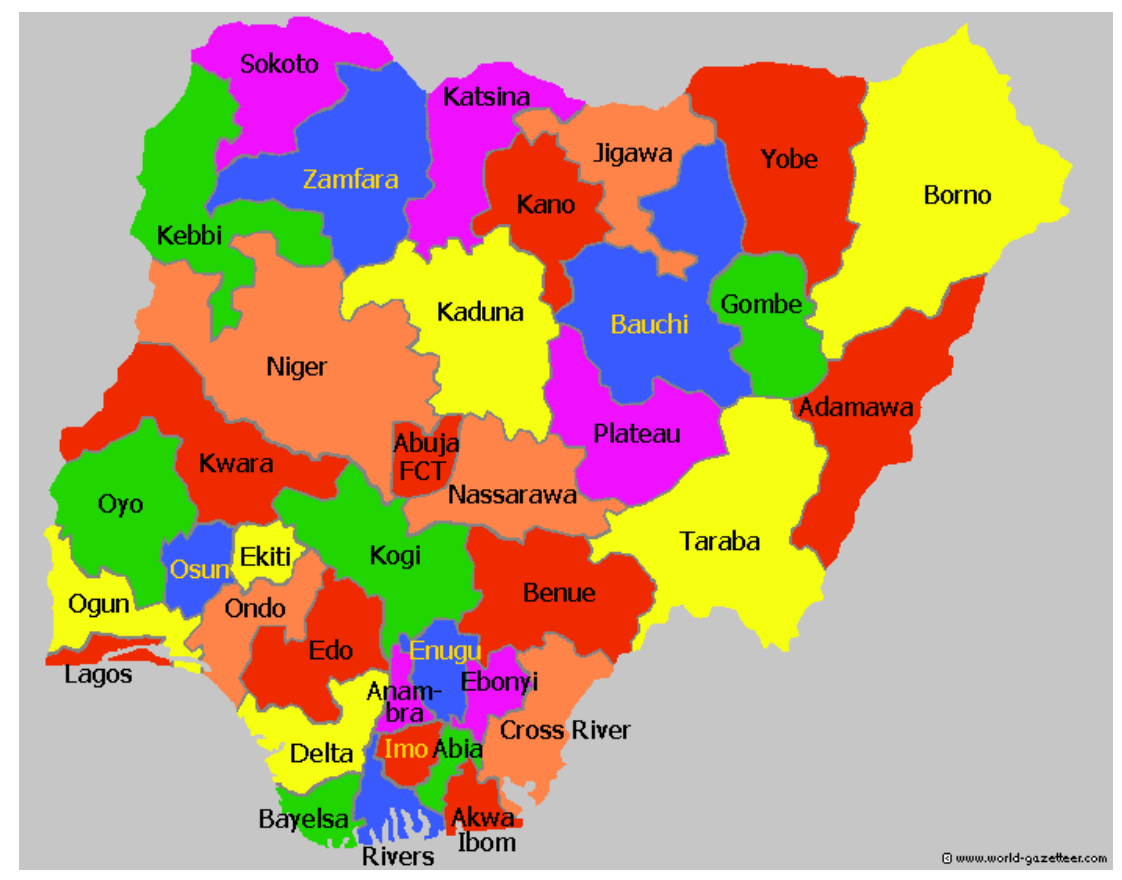

Figure 1: Map of Nigeria showing Kogi State. 


\section{Sampling}

Sediments from Okaba coal mine in Kogi State were obtained from five different sites in the mine area. They are:

1. sediment 1 (Omaji Oda sediment upstream);

2. sediment 2 (Omaji Oda sediment downstream);

3. sediment 3 (Achokpa sediment downstream);

4. sediment 4 (Achokpa sediment upstream); sediment);

5. sediment 5 ( Open pit mine site

Samples were dried on an inert material and pulverized using a mortar and pestle. $20 \mathrm{~g}$ of the sediment samples were individually and intimately mixed with a binder in the ratio of 5:1 cellulose flakes binder and pelletized at a pressure of $10-15$ tons/inch ${ }^{2}$ in a pelletizing machine. The pelletized samples are stored in desiccators for analysis.

\section{Instrumentation}

The instrument used was the energy dispersive $\mathrm{X}$-ray fluorescence spectrometer Panalytical B.V. MiniPal 4 model Lelyweg, Netherlands. It runs on a new version of software for MiniPal spectrometers that adds considerable flexibility for fast elemental analysis across the full spectrum of the entire periodic table. The MiniPal 4 software includes a variety of features that simplify applications set-up and data handling, such as re-calibration, spectra comparison, robust application defaults and extended calibration options. This instrument is equipped with a rhodium anode tube, 5 tube filters, a helium purge facility, high-resolution lithium -silicon drift detector and a 12-position removable sample changer with sample spinner. The tube setting is software controlled with a maximum power of $9 \mathrm{~W}$. The measuring time for each sample is 60 seconds in an air medium.

\section{Voltage settings}

The voltage settings for the analysis of various metals are in the following range: $\mathrm{Na} \rightarrow \mathrm{Cl}$ (4-12 V). The optimised voltage used is $8 \mathrm{~V} . \mathrm{K} \rightarrow \mathrm{V}(12-20 \mathrm{~V})$ has an optimised voltage of $18 \mathrm{~V} . \mathrm{Cr} \rightarrow \mathrm{Co}(20-25 \mathrm{~V})$ with an optimsed voltage of $25 \mathrm{~V}$ and $\mathrm{Ni} \rightarrow \mathrm{Ag}$ (25-30) with an optimized voltage of $28 \mathrm{~V}$. Energy dispersive X-ray fluorescence spectrometer is a non-destructive technique which is a key consideration in applications where the sample may need to be re-used.

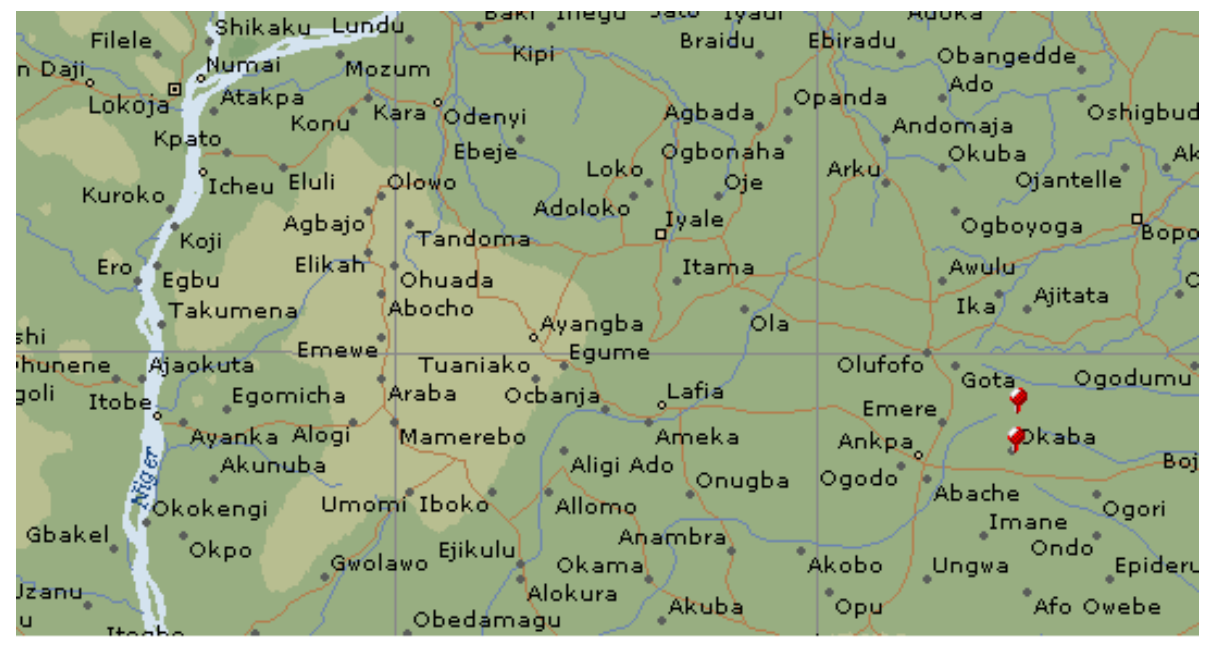

Figure 2: Map of Kogi State showing the study area marked with thumbnails. 


\section{RESULTS}

The result of the analysis of selected sediments for some heavy metals and nonmetals are presented in Table 1 below.

The results for the analyses of sediments from Okaba coal mine indicated high values for aluminum in sediments 3 and 4. At sediment 3 , the observed concentration is $14.08 \mathrm{mg} / \mathrm{g}$ at dry season and $13.85 \mathrm{mg} / \mathrm{g}$ at rainy season. This high concentration may be attributed to flooding at the downstream of Achokpa river as compared to sediment 4 at $12.00 \mathrm{mg} / \mathrm{g}$ (dry season) and $9.89 \mathrm{mg} / \mathrm{g}$ (rainy season). However, at sediment 2 , the observed concentrations are $9.20 \mathrm{mg} / \mathrm{g}$ and $10.68 \mathrm{mg} / \mathrm{g}$ at dry and rainy seasons respectively, while at sediment 1 a lower concentration of $7.01 \mathrm{mg} / \mathrm{g}$ and $7.05 \mathrm{mg} / \mathrm{g}$ were respectively observed for dry and rainy seasons. Silicon maintained a concentration range of $78.98-82.00 \mathrm{mg} / \mathrm{g}$ for sediments 1, 2 and 5. However, a concentration range of $43.68-58.01 \mathrm{mg} / \mathrm{g}$ was observed for sediments 3 and 4 . Phosphorus was not detected in all the samples. Sulphur was observed at sediment 3 with a concentration of $6.79 \mathrm{mg} / \mathrm{g}$ (dry season) and $6.06 \mathrm{mg} / \mathrm{g}$ (rainy season), and sediment 4 at $7.14 \mathrm{mg} / \mathrm{g}$ (dry season) and 7.78 $\mathrm{mg} / \mathrm{g}$ (rainy season).

Potassium showed a concentration range of $1.21 \mathrm{mg} / \mathrm{g}$ (dry season) - $0 \mathrm{mg} / \mathrm{g}$ (rainy season), $1.61 \mathrm{mg} / \mathrm{g}$ (dry season) -1.58 $\mathrm{mg} / \mathrm{g}$ (rainy season), $2.67 \mathrm{mg} / \mathrm{g}$ (dry season) $2.12 \mathrm{mg} / \mathrm{g}$ (rainy season), $2.37 \mathrm{mg} / \mathrm{g}$ (dry season) $-2.15 \mathrm{mg} / \mathrm{g}$ (rainy season) and 0.04 $\mathrm{mg} / \mathrm{g}$ (dry season) $-0 \mathrm{mg} / \mathrm{g}$ (rainy season) for sediments 1, 2, 3, 4 and 5 respectively. In the order of dry - rainy seasons, observed calcium concentration ranged from $0.23 \mathrm{mg} / \mathrm{g}-\mathrm{o}$ $\mathrm{mg} / \mathrm{g}, 0.29-0.25 \mathrm{mg} / \mathrm{g}, 0-0.31 \mathrm{mg} / \mathrm{g}, 0.38-$ $0.41 \mathrm{mg} / \mathrm{g}$ and $0.25-0 \mathrm{mg} / \mathrm{g}$ for sediments 1 , 2, 3, 4 and 5 respectively. The concentration range of titanium in sediment 1 is $1.14 \mathrm{mg} / \mathrm{g}$ (dry season) $-0 \mathrm{mg} / \mathrm{g}$ (rainy season) while at sediment 2 the observed concentration is 1.37 $\mathrm{mg} / \mathrm{g}$ (dry season) $-1.55 \mathrm{mg} / \mathrm{g}$ (rainy season).
Chromium indicated a low concentration of $0.01 \mathrm{mg} / \mathrm{g}$ dry season $-0 \mathrm{mg} / \mathrm{g}$ rainy season, $0.02 \mathrm{mg} / \mathrm{g}$ for both dry/rainy seasons, 0.04 $\mathrm{mg} / \mathrm{g}$ dry season $-0.06 \mathrm{mg} / \mathrm{g}$ rainy season, $0.05 \mathrm{mg} / \mathrm{g}$ dry season $-0.04 \mathrm{mg} / \mathrm{g}$ rainy season and $0.02 \mathrm{mg} / \mathrm{g}$ dry season $-0 \mathrm{mg} / \mathrm{g}$ rainy season for sediments $1,2,3,4$ and 5 respectively.

Manganese values are generally low for the five sediments with a range of 0.01 $\mathrm{mg} /-0.06 \mathrm{mg} / \mathrm{g}$ for dry season and $0 \mathrm{mg} / \mathrm{g}-$ $0.07 \mathrm{mg} / \mathrm{g}$ for rainy season. Vanadium concentration ranged from $0.02-0.08 \mathrm{mg} / \mathrm{g}$ dry season and $0-0.07 \mathrm{mg} / \mathrm{g}$ rainy season. The concentration trend followed a similar pattern as it increased from upstream to downstream. The concentration at sediment 5 is $0.02 \mathrm{mg} / \mathrm{g}$ dry season $-0 \mathrm{mg} / \mathrm{g}$ rainy season while that at sediment 3 is $0.08 \mathrm{mg} / \mathrm{g}$ dry season $-0.07 \mathrm{mg} / \mathrm{g}$ rainy season. Observed iron concentration range for dry - rainy seasons are $17.40-13.40 \mathrm{mg} / \mathrm{g}$ for sediment 4 and $15.27-20.73 \mathrm{mg} / \mathrm{g}$ for sediment 3 . Nickel was not detected at sediments 3 and 4 , while at sediments 2 and 5 the observed concentration is $0.01 \mathrm{mg} / \mathrm{g}$ for dry/rainy season and $0-0.01 \mathrm{mg} / \mathrm{g}$ for dry/rainy seasons respectively. Copper indicated a concentration range of $0.06-0.14 \mathrm{mg} / \mathrm{g}$ for dry season and $0-0.13 \mathrm{mg} / \mathrm{g}$ for rainy season.

Zinc concentrations were low at sediments 1 and 5 , but were not observed at sediments 2, 3 and 4 . The observed concentration at mine site could possibly come from the underlying coal material. Rubidium was observed at sediments 1 and 3, and could be attributed to its natural occurrence and leaching. It was not detected at sediments 2, 4 and 5 plausibly indicating its absence in the sedimentary strata of the coal deposits. Metals like zirconium, ruthenium, strontium, yttrium and barium were observed with ranges $0.02-0.45 \mathrm{mg} / \mathrm{g}, 0.39-1.40$ $\mathrm{mg} / \mathrm{g}, 0.01-0.07 \mathrm{mg} / \mathrm{g}, 0.02-0.07 \mathrm{mg} / \mathrm{g}$ and $0.08-0.10 \mathrm{mg} / \mathrm{g}$ respectively. Their observation in sediment 5 may indicate its 
presence in the underlying mineral matter. Increase in concentration at sediments $1-4$ may be attributed to flooding and percolation along the water course. Selenium, magnesium, sodium, niobium, mercury and tungsten were not detected in all the sediments. Furthermore, osmium, bismuth and antimony were detected at sediments 5, 1 and 3 respectively. These levels are not indicative of its presence in the underlying coal. Causes such as leaching could be ascribed to this case. Lead, scandium and arsenic levels are $0.13 \mathrm{mg} / \mathrm{g}$ rainy season (sediment 2 lead), $0.005-0.005 \mathrm{mg} / \mathrm{g}$ dry/rainy seasons (sediment 3 scandium), 0.01 - $0.01 \mathrm{mg} / \mathrm{g}$ dry/rainy seasons (sediment 3 scandium) and $0.02-0.02 \mathrm{mg} / \mathrm{g}$ dry/rainy seasons (sediment 2 arsenic). Bromine and chlorine were not detected in all the samples in conjunction with the following elements $\mathrm{P}$, $\mathrm{Se}, \mathrm{Na}, \mathrm{Br}, \mathrm{Cl}, \mathrm{Nb}, \mathrm{Hg}$ and $\mathrm{W}$.

Table 1: Some metallic and non-metallic compositions of sediments from Okaba coal mine, Kogi State $(\mathrm{mg} / \mathrm{g})$.

\begin{tabular}{|c|c|c|c|c|c|c|}
\hline Parameter & $\begin{array}{l}\text { Seasonal } \\
\text { variation }\end{array}$ & Sediment 1 & Sediment 2 & Sediment 3 & Sediment 4 & Sediment 5 \\
\hline \multirow[t]{2}{*}{$\mathrm{Al}$} & Rainy & 7.01 & 9.20 & 14.08 & 12.00 & 0.98 \\
\hline & Dry & 7.05 & 10.68 & 13.85 & 9.89 & 1.01 \\
\hline \multirow[t]{2}{*}{$\mathrm{Si}$} & Rainy & 79.60 & 78.98 & 53.80 & 53.10 & 79.90 \\
\hline & Dry & 79.61 & 82.00 & 43.68 & 58.01 & 81.00 \\
\hline \multirow[t]{2}{*}{$S$} & Rainy & ND & ND & 6.79 & 7.14 & ND \\
\hline & Dry & $N D$ & 0.03 & 6.06 & 7.78 & $N D$ \\
\hline \multirow[t]{2}{*}{$\mathrm{K}$} & Rainy & ND & 1.61 & 2.67 & 2.37 & 0.04 \\
\hline & Dry & 1.21 & 1.58 & 2.12 & 2.15 & $N D$ \\
\hline \multirow[t]{2}{*}{$\overline{\mathrm{Ca}}$} & Rainy & 0.23 & 0.29 & ND & 0.38 & 0.25 \\
\hline & Dry & $N D$ & 0.25 & 0.31 & 0.41 & $N D$ \\
\hline \multirow[t]{2}{*}{$\mathrm{Ti}$} & Rainy & 1.14 & 1.37 & 1.27 & 2.23 & 0.14 \\
\hline & Dry & $N D$ & 1.55 & 1.97 & 2.10 & $N D$ \\
\hline \multirow[t]{2}{*}{$\mathrm{Cr}$} & Rainy & 0.01 & 0.02 & 0.04 & 0.05 & 0.02 \\
\hline & Dry & $N D$ & 0.02 & 0.06 & 0.04 & $N D$ \\
\hline \multirow[t]{2}{*}{$\mathrm{Mn}$} & Rainy & 0.01 & 0.02 & 0.04 & 0.06 & 0.02 \\
\hline & Dry & $N D$ & 0.03 & 0.07 & 0.05 & $N D$ \\
\hline \multirow[t]{2}{*}{$\mathrm{V}$} & Rainy & 0.03 & 0.04 & 0.08 & 0.08 & 0.02 \\
\hline & Dry & $N D$ & 0.04 & 0.07 & 0.06 & $N D$ \\
\hline \multirow[t]{2}{*}{$\mathrm{Fe}$} & Rainy & 1.14 & 1.86 & 15.27 & 17.40 & 1.21 \\
\hline & Dry & $N D$ & 2.24 & 20.73 & 13.40 & $N D$ \\
\hline \multirow[t]{2}{*}{$\mathrm{Ni}$} & Rainy & 0.008 & 0.01 & ND & ND & ND \\
\hline & Dry & $N D$ & 0.01 & $N D$ & $N D$ & 0.01 \\
\hline \multirow[t]{2}{*}{$\mathrm{Cu}$} & Rainy & 0.06 & 0.06 & 0.09 & 0.14 & 0.06 \\
\hline & Dry & $N D$ & 0.09 & 0.07 & 0.13 & $N D$ \\
\hline \multirow[t]{2}{*}{$\mathrm{Zn}$} & Rainy & ND & ND & ND & ND & ND \\
\hline & Dry & 0.007 & $N D$ & $N D$ & $N D$ & 0.01 \\
\hline \multirow[t]{2}{*}{$\mathrm{Rb}$} & Rainy & 0.006 & ND & 0.03 & ND & ND \\
\hline & Dry & $N D$ & $N D$ & $N D$ & $N D$ & $N D$ \\
\hline $\mathrm{Zr}$ & Rainy & 0.29 & 0.25 & 0.27 & 0.45 & 0.02 \\
\hline
\end{tabular}




\begin{tabular}{|c|c|c|c|c|c|c|}
\hline & Dry & $N D$ & 0.35 & 0.23 & 0.41 & $N D$ \\
\hline \multirow[t]{2}{*}{$\mathrm{Ru}$} & Rainy & 0.39 & 0.42 & 0.58 & 1.40 & 0.49 \\
\hline & Dry & 0.34 & 0.42 & 0.58 & 1.40 & 0.49 \\
\hline \multirow[t]{2}{*}{$\mathrm{Ba}$} & Rainy & ND & ND & ND & ND & 0.01 \\
\hline & Dry & $N D$ & $N D$ & 0.10 & 0.10 & 0.08 \\
\hline \multirow[t]{2}{*}{$\mathrm{Sr}$} & Rainy & ND & 0.01 & 0.05 & 0.07 & ND \\
\hline & Dry & $N D$ & 0.02 & 0.06 & 0.06 & $N D$ \\
\hline \multirow[t]{2}{*}{$\mathrm{Y}$} & Rainy & 0.02 & ND & 0.03 & 0.07 & 0.02 \\
\hline & Dry & 0.02 & $N D$ & 0.03 & 0.07 & $N D$ \\
\hline \multirow[t]{2}{*}{ Os } & Rainy & ND & ND & ND & ND & 0.02 \\
\hline & Dry & $N D$ & $N D$ & $N D$ & $N D$ & $N D$ \\
\hline \multirow[t]{2}{*}{$\overline{\mathrm{Bi}}$} & Rainy & 0.04 & ND & ND & ND & ND \\
\hline & Dry & $N D$ & $N D$ & $N D$ & $N D$ & $N D$ \\
\hline \multirow[t]{2}{*}{$\mathrm{Sb}$} & Rainy & ND & ND & 0.26 & ND & ND \\
\hline & Dry & ND & $N D$ & 0.26 & $N D$ & ND \\
\hline \multirow[t]{2}{*}{$\mathrm{Pb}$} & Rainy & ND & ND & ND & ND & ND \\
\hline & Dry & $N D$ & 0.13 & $N D$ & $N D$ & $N D$ \\
\hline \multirow[t]{2}{*}{$\mathrm{Sc}$} & Rainy & ND & ND & 0.005 & 0.01 & ND \\
\hline & Dry & $N D$ & $N D$ & 0.005 & 0.01 & $N D$ \\
\hline \multirow[t]{2}{*}{ As } & Rainy & ND & 0.02 & ND & ND & ND \\
\hline & Dry & $N D$ & 0.02 & $N D$ & $N D$ & $N D$ \\
\hline \multirow[t]{2}{*}{$\overline{\mathrm{Au}}$} & Rainy & ND & ND & ND & ND & 0.03 \\
\hline & Dry & $N D$ & $N D$ & $N D$ & $N D$ & $N D$ \\
\hline
\end{tabular}

$\mathrm{ND}=$ Not detected. Italicized bold values are analyses carried out during rainy season.

\section{DISCUSSION}

These differences in $\mathrm{Al}$ concentration could be attributed to flooding. Other factors that could contribute to this variation in aluminum concentration in the sediments include chemical speciation, hydrological flow paths, soil-water interactions, and the composition of the underlying materials. Acid environment caused by acid mine drainage or acid rain can cause an increase in the dissolved aluminum content of the surrounding waters (ATSDR, 1992). Aluminum intake from foods, particularly those containing aluminum compounds used as food additives represent the major route of aluminum exposure for the general public, excluding persons who generally ingest aluminum-containing antacids and buffered analgesics (W.H.O, 1997). For inhabitants living at the downstream of Achokpa river, over exposure and acute toxicity in crops may lead to behavioural impairment at doses exceeding $200 \mathrm{mg}$ of aluminum per $\mathrm{Kg}$ of body weight per day (Connor, 1988; YenKoo, 1992).

The decline in Si concentration could be attributed to flooding of the river bed. Overburden piles also contain more silicon matter (sediments 1 and 2) which are finely divided and readily wind-blown spreading contaminants and fibres that can cause the full spectrum of respiratory conditions from irritation to lung cancer. High levels of silicon matter have been shown to overwhelm immune functions in this regard. The observed sulphur concentration may be ascribed to biogeochemistry of sulphur from the acidic mine drainage. The results obtained with some previous work on sulphur speciation in coal 
(Triese, 1998; Laban and Atkin, 2000; Selsbo, 1996; Chou and Buchanan, 1995).

The low value of $\mathrm{K}$ could be attributed to leaching, composition of the underlying materials and flooding (W.H.O, 1997). The observed $\mathrm{Ca}$ variations could be attributed to leaching as the water flows to the downstream as in the case of sediments 3 and 4 . However, sediment 1 being valley-like sediment underlying the overburden may not be rich in calcium and accumulation as a result of flooding increased the concentration slightly as in the case of sediment 2 . The correlates to the mine site sediment (sediment 5) indicating original concentration of calcium in the coal sediments. The observed increment in $\mathrm{Ti}$ concentration may be ascribed to flooding at the downstream path of the water trajectory. However, chemical speciation of titanium may account for the slight increase at the downstream. This trend is not applicable to sediments 3 and 4 where the values of titanium decreased from the upstream to the downstream. Chemical speciation and the composition of the underlying material may be responsible for this slight decrease (1.27 $\mathrm{mg} / \mathrm{g}$ dry season $-1.97 \mathrm{mg} / \mathrm{g}$ rainy season and $2.23 \mathrm{mg} / \mathrm{g}$ dry season - $2.10 \mathrm{mg} / \mathrm{g}$ rainy season for sediments 3 and 4 respectively). At biotoxic level, titanium could have deleterious effect on humans as it is capable of retarding mental development.

Flooding and chemical speciation may be responsible for the increase in $\mathrm{Cr}$ from upstream to downstream. This observed low values agreed with the works of previous research in chromium speciation (Goodarzi and Huggins, 2001; Andres-Garcia and Blanco-Gomis, 1997; Huggins, 1993). Low values of Mn may be due to exposure of the sediments to oxidative processes and to some extent acidic leaching. It is interesting to note that most of the sediments are in the anoxic conditions. Earlier studies have shown that if the anoxic sediments are exposed to the atmosphere, the metal speculations will move to the more mobile forms (Helios-Rubicka et al., 2000). Oxidative processes and acidic leaching may account for the increase in $\mathrm{V}$ concentration. This increment is part of the introduction of pollutant into a natural system as persons living at the downstream are exposed to metals at biotoxic levels. The mobility of iron in solution may be responsible for this increase (Wasserman et al., 1996; Taneja et al., 1993). Flooding may however play an important role in this increase.

Several factors may account for the low concentration observed Ni. Factors such as acid drainage increase the mobility of nickel in the soil and thus might increase nickel concentrations in ground water (IPCS, 1991). Leaching may also be a factor that diminishes the concentration of nickel in the sediments (Schwenk, 1992). Composition of the underlying material could also be ascribed as the potential source of decrease in nickel concentration. Acute exposure may result in cardiac arrest in humans. The results recorded agreed with result of previous work on nickel in coal and its sediments (Goodarzi and Huggins, 2001; Shirai et al., 1997).

The detected copper concentration was plausibly due to the composition of the underlying material. However a tendency for biotoxicity of copper to occur at the downstream is very high. Studies has revealed that the fate of elemental copper in water and soil is complex and influenced by $\mathrm{pH}$, dissolved oxygen, and the presence of oxidizing agents and complexing compounds or ions (USEPA, 1995). Surface oxidation of copper produces copper (I) oxide or hydroxide. In most instances, copper (I) ion is subsequently oxidized to copper (II) ion. However, copper (I) ammonium and copper (I) chloride complexes, when they form, are stable in aqueous solution. Because copper is a naturally occurring element, it is found ubiquitously in surface water, ground water, sea water, and drinking water (ATSDR, 
1990). Research has also shown that individuals ingesting large doses of copper present with gastrointestinal bleeding, haematuria, intravascular haemolysis, methaemoglobinaemia, hepatocellular toxicity, acute renal failure and oliguria (Agarwal et al., 1993).

The low levels of arsenic may be due to leaching as reported in previous work in literature (Cullen and Reimer, 1989; Goodarzi and Huggins, 2001; Karayigit et al., 2001; Kolker et al., 2000).

\section{Conclusion}

Coal sediments do not just contain one harmful material but many. The effect of accumulation of multiple toxic metals in plants, animals and humans is almost certain to exact a compounding of individual harmful effects and cause ultimately a catastrophic breakdown in health to those affected especially at the downstream (sediments 2 and 3). Coal sediments of Okaba coal mine contain biotoxic levels of $\mathrm{Al}, \mathrm{Si}, \mathrm{K}, \mathrm{Ti}, \mathrm{Cr}$, $\mathrm{Mn}, \mathrm{Fe}, \mathrm{Cu}, \mathrm{Zr}, \mathrm{Ru}, \mathrm{Sr}$ and $\mathrm{Y}$. these elements are capable of being taken up by plants and farming animals in toxic levels and thereby enter the food chain in humans. Most of the toxic metals exert their effect by being absorbed or taken up preferentially if the required nutritional minerals are in deficit. Once within the body, toxic metals interfere irreversibly with enzyme processes. The liberation of heavy metals into our environment has been shown to be persistent that is non-biodegradable, concentrated in sediments and cumulative in plant and animal tissue resulting in both acute and long-term bio-toxicity. It was also noted that overburden piles contain more siliceous matter which are finely divided and readily wind-blown. Radioactive elements within the sediments are not significant or not present further signifying its absence in the underlying mineral of coal.

\section{REFERENCES}

Adaikpoh EO, Nwajei GE, Ogala JE. 2005. Heavy metals concentrations in coal and sediments from River Ekulu in Enugu, Coal city of Nigeria. J. Appl. Sci. Environ. Mgt., 9(3): 5 - 8.

Agarwal SK, Tiwari SC, Dash SC. 1993. Spectrum of poisoning requiring hemodialysis in a tertiary care hospital in India. Int. J Artificial Organs, 16(1): 2022.

Alka RU, Tripathi BD. 2007. Principle and process of biofiltration of $\mathrm{Cd}, \mathrm{Cr}, \mathrm{Ni}$ and $\mathrm{Pb}$ from tropical opencast coal mine effluent. Water, Air \& Soil Pollution, 180(1-4): 213 - 223.

Andres-Garcia E, Blanco-Gomis D. 1997. Speciation analysis of chromium using cryptand ethers. Analyst (Cambridge, UK), 122(9): 899 - 902.

ATSDR. 1990. Toxicological Profile for Copper. US Department of Health and Human Services, Public Health Service, Agency for toxic Substances and Disease registry: Atlanta, GA,

ATSDR. 1992. Toxicological Profile for Aluminum. US Department of Health and Human Services, public Health Service, Agency for Toxic Substances and Disease Registry: Atlanta, GA.

Biswas A, Blum JD, Berqquist AB, Keeler GJ. Xie Z. 2008. Natural mercury isotope variation in coal deposits and organic soils. Environ Sci. Technol., 42(22): 8303 - 8309 .

Chou M-IM, Buchanan DH. 1995. Sulphur speciation of desulphurised coals by XANES spectroscopy. Fuel, 74(4): 549555.

Connor DJ, Jope RS, Harrell LE. 1988. Chronic, oral aluminum administration to rats: cognition and cholinergic parameter. Pharmacology, Biochemistry \& Behaviour, 31: 467 - 474. 
Cullen WR, Reimer KJ. 1989. Arsenic speciation in the environment: Chemical Reviews, 89(4): 713 - 764.

Franciskovic-Bilinski S. 2008. Detection of coal combustion products in stream sediments by chemical analysis and magnetic-susceptibilty measurements. Mineralogical Magazine, 72(1): 43 - 48.

Goodarzi F, Huggins FE. 2001. Monitoring the species of arsenic, chromium and nickel in milled coal, bottom ash and fly ash from a pulverized coal-fired power plant in western Canada. J. Environ. Monit., 3(1): 1-6.

Hamilton-Taylor J, Edmunds WM, Darling WG, Sutcliffe DW. 1988. A diffusive ion flux of non-marine origin in Cumbrian lake sediments; Implications for element budgets in catchments. Geochimica et Cosmochimica Acta, 52(1): 223 - 227.

Helios-Rubicka E, Knochel A, Academic E, Meye AK, Poprawski L. 2000. Crucial loads in the river Oda - impacts of floods on the situation of harzardous substances, ATV-DVWK-schriftenreihe 21, Gewasser Landshaften, 79 - 99.

Huggins FE, Shah N, Zhao J, Lu F, Huffman GP. $\quad$ 1993. Non-destructive determination of trace element speciation in coal and coal ash by XAFS (X-ray absorption fine structure) spectroscopy. Energy-Fuels, 7(4): 482 489.

IPCS. 1991. Nickel. World Health Organisation, International Programme on Chemical Safety (Environmental Health Criteria 108): Geneva.

Joy ER, Andrew P. 1996. Techniques for validating the historic record of lake sediments. A demonstration of their use in the English Lake District. Applied Geochemistry, 11(1-2): $211-215$.

Karayigit AI, Onalak T, Gayer RA, Goldsmith S. 2001. Mineralogy and geochemistry of feed coals and their combustion residues from the Cayirhan power plant, Ankara, Turkey. Applied Geochem., 16: $911-919$.

Kolker A, Huggins FE, Palmer CA, Shah N, Crowley SS, Huffmann PG, Finkelman RB. 2000. Mode of occurrence of arsenic in four US coal. Fuel Process. Tech., 63: $167-178$.

Laban KL, Atkin BP. 2000. The direct determination of the forms of sulphur in coal using microwave digestion and ICP AES analysis. Fuel, 79(2): $172-180$.

Porter SD, White KD, Clark JR. 1995. Waterquality assessment of the Kentucky River Basin, Kentucky: Distribution of metals and other trace elements in sediments and water, 1987 - 90: U.S. Geological Survey water Resources investigations Report 94 - 4134, p 184.

Schwenk W. 1992. Nickel transfer from Cr-Ni stainless steel pipework into portable water. GWF Wasser Abwasser, 133: 281-286.

Selsbo P, Almen P, Ericsson I. 1996. Quantitative analysis of sulphur in coal by pyrolysis-gas chromatography and multivariate data analysis. Energy Fuels, 10(3): 751 - 756.

Shirai M, Murakami K, Nishiyama Y. 1997. In situ EXAFS of nickel species during pyrolysis of brown coals. Energy-Fuels, 11(5): 1012 - 1018.

Taneja SP, Aggarwall MP, Brar AS. 1993. Hyperfine and X-ray studies of coal and coal ash. Nucl-Instrum Methods Phys Res Sect-B, B76: 236 - 238.

Tariq S, Joselito MA, Ronald WT and Yiqiang Z. 2007. Bacterial reduction of selenium in coal mine tailings pond sediment. J. Environ Qual., 36: 621 627.

Triese K, Wendt-potthoff K, Zachmann DW, Fauville A, Mayer B, Viezer J. 1998. Biogeochemistry of iron and sulphur in sediments of an acidic minning lake in 
lusatia, Germany. Water, Air \& Soil Pollution, 108(3-4): 231-247.

US EPA. 1995. Effect of $p H$, DIC, Orthophosphate and Sulphate on Drinking Water Cuprosolvency. US Environmental Protection Agency, Office of Research and development. Washington, DC.

Wasserman SR, Winans RE, McBeth R. 1996. Iron species in Argonne premium coal samples: an investigation using X-ray absorption spectroscopy. Energy-Fuels, 10(2): $392-400$.

WHO. 1997. Aluminum. World Health Organization, International Programme on Chemical Safety (Environmental Health Criteria 194). Geneva.

Widod S, Oschmann W, Bechtel A, Sachsenhofer RF, Anggyana K,
Puettmann W. 2010. Distribution of sulphur and pyrite in coal seams from Kutai basin (East Kalimantan, Indonesia): Implications for paleoenvironmental conditions. Int. J Coal Geology, 81(3): 151 - 162.

Yen-Koo HC. 1992. The effect of aluminum on conditioned avoidance response (CAR) in mice. Toxicol \& Indust. Health, 8: $1-7$.

Zhang Q, Hua-Wen Q, Rui-Zhong H. XiaoFei W. 2008. Mineralogy of Ge-bearing coal from Wulantuga super large Germanium deposit, inner Mongolia, China. Acta Minerologica Sinica, 28(4): 426-438. 